\title{
Study on Representation of Gender in Indian Print Media: A Semiotic Analysis of Fast-Moving Consumer Goods (FMCG) Advertisements
}

\author{
REVATHY R ${ }^{1}$, BHARGAVI D HEMMIGE ${ }^{2}$ \\ ${ }^{1}$ JAIN (DEEMED-TO-BE) UNIVERSITY. Email: revureghu@gmail.com \\ ${ }^{2}$ Department of Media Studies, JAIN (DEEMED-TO-BE) UNIVERSITY, BENGALURU, INDIA
}

\begin{abstract}
The categorisation of gender into femininity and masculinity is purely a social construct. Advertising is a social institution that plays a significant role in promoting notions of gender identities at a symbolic level (Gilbert and Taylor, 1991). This study aims to understand the manifestation of masculinity and femininity in contemporary Indian print advertisements of popular Fast Moving Consumer Goods (FMCG). This study uses the theory of visual social semiotics for the analysis adopting the framework propounded by Gunther Kress and Theo Van Leeuwen (1996; 2006). The representational and interactive dimensions from the framework will be used for the analysis of the advertisements. This will be further thematised to understand the nature of the representation of masculinity and femininity in them. It will also provide an insight into the relationship between the viewers and participants of these advertisements. The data for the current study includes three popular Indian magazine advertisements of FMCG products published between the years 2019-2020, selected using a purposive sampling technique.
\end{abstract}

Keywords: Print advertisements; Visual semiotics; Gender representation; FMCG

JEL Classification: C1, L2 


\title{
Estudio sobre la Representación del Género en los Medios Impresos Indios: Un Análisis Semiótico de los Anuncios de Bienes de Consumo Rápido (FMCG)
}

\author{
REVATHY R ${ }^{1}$, BHARGAVI D HEMMIGE ${ }^{2}$ \\ ${ }^{1}$ JAIN (DEEMED-TO-BE) UNIVERSITY. Email: revureghu@gmail.com \\ ${ }^{2}$ Department of Media Studies, JAIN (DEEMED-TO-BE) UNIVERSITY, BENGALURU, INDIA
}

\begin{abstract}
RESUMEN
La categorización del género en feminidad y masculinidad es puramente una construcción social. La publicidad es una institución social que desempeña un papel importante en la promoción de las nociones de identidad de género a nivel simbólico (Gilbert y Taylor, 1991). Este estudio pretende comprender la manifestación de la masculinidad y la feminidad en los anuncios impresos indios contemporáneos de populares productos de consumo rápido (FMCG). Este estudio utiliza la teoría de la semiótica social visual para el análisis, adoptando el marco propuesto por Gunther Kress y Theo Van Leeuwen (1996; 2006). Para el análisis de los anuncios se utilizarán las dimensiones de representación e interacción del marco. Esto se tematizará aún más para comprender la naturaleza de la representación de la masculinidad y la feminidad en ellos. Asimismo, permitirá conocer la relación entre los espectadores y los participantes de estos anuncios. Los datos para el presente estudio incluyen tres anuncios populares de revistas indias de productos de gran consumo publicados entre los años 2019-2020, seleccionados mediante una técnica de muestreo intencional.
\end{abstract}

Palabras clave: Anuncios impresos; Semiótica visual; Representación de género; Productos de gran consumo

Clasificación JEL: C1, L2 


\section{Introduction}

Media has a dynamic role in the social progression and transformation of society by disseminating information. The constructive role of media in creating public awareness and shaping opinions among the people makes it the fourth pillar of the world's largest Democracy-India. Mass media function to entertain, amuse, inform, and impart individuals with codes of behaviour and values and beliefs that will allow them to integrate into the institutional structures of the society (Herman \& Chomsky, 1988).

Advertisements play a significant role in everyday life's symbolic and factual milieu (Tavin, 2005). Advertising should stop the consumers and hold their complete attention in pleasant ways because where the eye stops, the sale begins (Pieters, Wedel and Batra, 2010). According to the American Marketing Association (2012), advertising is a paid form of communication to promote goods, services or ideas by an identified sponsor. In this paper, the researcher aims to analyse the portrayal of gender in FMCG products' print advertisements published in India, using visual social semiotics as the theoretical framework. The advertisements will be studied and analysed using Kress and Theo Van Leeuwen's semiotic framework. They will be further thematised to understand the nature of the representation of masculinity and femininity in selected media texts.

Society claims to be immune to advertisements and their effects. According to Jean Kilbourne (2000), we are exposed to more than 3000 advertisements a day. More than selling products or services, advertisements sell images, values, concepts of sexuality, gender, love, gender roles, success, failure, popularity and normalcy. She says advertisements are the foundation of mass media. It tells us who we are and how we should be. Schudson (1984) states that the promotional culture of advertising has successfully found its way into influencing how we think, care, raise our kids, how we shape our perspectives and ideologies (p.13).

While studying advertising, particular importance should be given to visual representation through images as non-verbal symbols. Since advertising is a socialising agent, the imagery given by the medium can have a powerful impact on our values, beliefs, attitudes, behaviour and culture itself, as it can contribute associations and meanings apart and of greater significance. Advertisements are not merely invisible conveyers of messages, or they do not reflect the reality of lives transparently; they are specific structures of signs or definite discourses (Gillian Dyer, 2009). Modern advertisements use images extensively, and these images are powerful symbols that can convey meanings as proficiently as verbal symbols.

Like verbal symbols, images also create multi-dimensional meanings that should be decoded for understanding. According to Arens and Bovee (1986), most readers/spectators of the advertisements first look at the illustration and then only read the text included in that advertisement. Hence images have a vital role in decoding a message from an advertisement.

Gender is purely a social construct. It is the culturally established categories of sex - male and female. Studies on the representation of genders in advertising has a recent origin dating back to the early '70s. Previous researches have proved and established that advertisements stereotype gender roles and images. For example, advertisements have constantly confined women to domestic roles and have portrayed them as generally weaker, dependent and irrational. Advertisements play a vital role, particularly in the portrayal of men and women relations and their roles. They reinforce the stereotypical representation of gender and influence our concepts of gender roles, especially by using varied imageries. It creates a "pseudo-reality" that is better than the real one (Goffman, 1978). India is the third-highest contributor to the gradational ad spends after USA and UK. According to the TYNY forecast conducted in February 2020 on advertising expenditure (adex), India will continue to top the list of the world's largest and fastest-growing major ad markets. India's investment in advertising will reach an estimate of 91,641 crores in 2020. It represents $10.7 \%$ estimated growth for this calendar year (Indian Ad Spends Estimated to Grow at 10.7\% in 2020: 's TYNY Report, 2020).

FMCGs are those small scale fast-moving consumer purchases that can be made at any small grocery store and supermarket (Investopedia, 2018). They are referred to as product which is 
relatively low cost and are often purchased by consumers. FMCGs have a short shell life and less profit margin. Print advertisements for FMCG products influence the readers a lot. According to Statista Research Department (2020), India is one of the fastest-growing advertising markets in Asia. Fast-moving consumer goods (FMCG) products, e-commerce and automobile, are the most advertised industries in the country. Tradition media platforms such as TV, radio and print are still among the popular advertising platforms in India even after the advent of digital media. As per the reports of the India Brand Equity Foundation (IBEF) (2018), the Fast Moving Consumer Goods (FMCG) sector is the fourth largest sector in the Indian economy. According to a survey conducted by IBEF, India's contribution to global consumption will double by 5.8 per cent in 2020 . The consumption was 60 million tons in the financial year 2018. The industry is expected to grow as a 103.7 billion-dollar industry in India by 2020. One of the primary reasons for this is the growth of the FMCG market at a faster pace in rural India compared with urban India. Rural consumption of branded FMCG products has increased with better income levels combined with greater aspiration levels.

\section{Review Of Literature}

\subsection{Advertising as Communication (2009)}

In her book 'Advertising as communication', Gillian Dyer discusses the basic concepts, ideas, and materials for studying advertisements. Advertising influences our thoughts, feelings, and lives, and we must be aware of its powerful effects and equip ourselves to use it wisely as a form of social communication. Content analysis of an advertisement involves both verbal and visual aspects of the text, and regarding the text, it is considered more potent than any written or spoken materials. Advertisements organise and construct reality through the ideologies and meanings it produces within the ad discourse.

\subsection{Decoding Advertisements (1978)}

Judith Williamson provides a significant structural and cultural analysis of advertising in the book 'Decoding advertisements'. She discusses the ideological practices in advertising by which goods are provided with a given meaning. According to her, advertisements alter the "use value" of projects into the "exchange value" of supplies. This is termed as the "metastructure" by Williamson in which the meaning is not decoded within one structure but it is shifted to create another. Meaning is created through the audience and it is not thrust at them by the advertisements. There is an exchange of meaning that happens between the advertiser and the audience, and this exchange depends upon the spectator's cultural knowledge and background.

\subsection{A Semiotic Analysis of Iconic Representation of Women in the Middle Eastern Media}

Sarah Ahmed Adham (2012) published a study on the semiotic analysis of the representation of women in the Middle Eastern media. The study mainly focused on how various semiotic resources were used in conveying precise messages to the viewers. To do the semiotic analysis of the texts, the Kress and Van Leeuwen Framework for reading visual images was used. According to her study, the texts, designs, images and colours used in advertisements in Saudi Arabia are designed to show men are active and superior to women in life.

\subsection{Multimodal Discourse: A Visual Design Analysis of Two Advertising Images (2015)}

Tan Han Ly and Chae Kwan Jung explore the value of imageries as a semiotic resource in communication usually neglected. The published study focuses on decoding two digital advertising images using the theoretical framework of Kress and Leeuwen on visual semiotics. The grammar of visual designs in western culture is the grammar of contemporary visual design, and it stays side by side with the local forms. Westernisation can be found in South East Asian magazine advertisement contents. According to the study, the theoretical framework by Kress and Leeuwen is proficient in 
decoding the meaning potential of the advertising images. The study has also proved that images have the potential to deliver multi-levelled meanings. Images as a semiotic resource can play a prominent role in communication.

\section{Theoretical Framework}

Semiotics is the study of signs and symbols. It is the fusion of signifier and meaning/form and signified. Semiotics explores symbols and signs as a substantial part of communication. A sign can be an image, a sound or a word. According to Saussure, a sign is divided mainly into two components. The signifier and the signified. The signifier can be the image, text or sound, and the signified is the concept or meaning represented by the signifier. Social semiotics is another sub-domain that studies the significant human practices in explicit cultural and social circumstances tries to describe meaning-making as a practice in society. It also discusses how humans use different signs to build the life of a particular community. This is relevant because communities are all different in their traditions, customs and beliefs. The signs used by one community for communicating one idea, thought, or feeling will have a different meaning when the same sign comes to a different community.

Theory of visual social semiotics by Gunther Kress and Theo Van Leeuwen $(1996 ; 2006)$ is used as the primary exploration tool for decoding the meaning of the visual texts from the selected advertisements of FMCG products. The concept of social semiotics is used mainly to analyze the signs and symbols that represent the significant human practices in an explicit culture and social circumstances. Analysis of the images is attempted based on the representational and interactive dimensions formulated by Kress and Leeuwen.

The representational dimension stems from Michael Halliday's ideational metafunction. It tries to represent the relationships that exist between things in the world and within us. This dimension has mainly two processes under it, the narrative and conceptual processes. Kress and Leeuwen state that the narrative process is dynamic and it represents unfolding events, actions, transitory spatial arrangements and many more. In the narrative process, the represented participant in the advertisement will be connected by a vector, which is a line formed by the varied elements on the image. Vectors can be formed by bodies, tools in action, limbs etc., when participants are shown as doing something to or for each other in the ads. It can be the eye-lines or even the gestures pointing in a particular direction. Those who create these vectors are called "actors", and the participants who receive them is the "goal".

The interaction between the image viewer and the producer is the second dimension in Kress and Leeuwen's framework. This dimension is inspired by and based on Halliday's interpersonal function. According to them, the message producers use the participants' gaze to encrypt social meanings into the imageries visually. The gaze which demands something from the viewer establishes types of demand relations. Social distance, modality and angle/point of view are also aspects that produce relations between the participant and the viewer and how viewers judge the images and their realism.

\section{Objective Of The Research}

The study mainly aims to analyse the visual grammar of selected print advertisements using Kress and Van Leeuwen's visual social semiotic theoretical framework. The researcher has further thematised this analysis to understand the representation of gender in advertisements for FMCG products.

To get a clearer perception, the researcher has tried to analyse the advertisements based on the following parameters:

- Gender roles prevalent in print ads

- Recurring themes in representing the genders 
- Gender representation and product categories

- The relationship established between the represented participant in the advertisement and the viewer

\section{Research Design And Method}

This is a qualitative study using content analysis as the research tool.

Print advertisements published between 2019-2020 were selected as sample units for this study. Three advertisements of FMCG products (Fast-moving consumer goods) featuring human subjects were selected by the researcher from the most popular Indian English magazines published during the year 2019-2020. These purposely selected samples of advertisements are from the magazines, The Femina and Woman's Era. These magazines are selected based on their popularity as the largest best-selling magazines in India as per the readership survey of India in 2019.

\section{Inclusion And Exclusion Criteria}

\section{Inclusion criteria}

- Indian English magazine advertisements of FMCG products published between the year 2019-2020

- Indian magazine advertisements of FMCG products representing gender

Exclusion criteria

- Non-Indian advertisements

- Indian magazine advertisements published before the year 2019

- Indian magazine advertisements which are not advertising an FMCG product

- $\quad$ FMCG product advertisements that do not represent genders in them

- Regional language magazines published in India

\section{Analysis And Findings}

\begin{tabular}{|c|c|c|}
\hline $\begin{array}{l}\text { Genders } \\
\text { represented in } \\
\text { the } \\
\text { advertisements }\end{array}$ & $\begin{array}{l}\text { Main visual semiotic } \\
\text { reso urces used in the selected } \\
\text { text }\end{array}$ & Meanings derived/messages being emitted in the text \\
\hline $\begin{array}{l}\text { Fem ale } \\
\text { participant - one } \\
\text { Male participant- } \\
\text { Two }\end{array}$ & $\begin{array}{l}\text { 1. Eye gaze - vectors are used } \\
\text { to connect the female } \\
\text { participant to male } \\
\text { 2. Yellow and red color used in } \\
\text { foreground is most salient in } \\
\text { the text } \\
\text { 3. Black and white color with } \\
\text { thin font } \\
\text { 4. Foregrounding of product } \\
\text { 5. A specific social setting in } \\
\text { the visual composition-family } \\
\text { 6. Portrayal of female in } \\
\text { kitchen } \\
\text { 7. The westem clothing of the } \\
\text { fem ale participant } \\
\text { 8. Space- Kitchen }\end{array}$ & $\begin{array}{l}\text { Social; ex udes warm th, social } \\
\text { affinity, message of 'Mother knows } \\
\text { best...' is emitted } \\
\text { Reflecting Indian family values } \\
\text { Reflecting the ideologies of a patriarchal society were } \\
\text { wom an is confined to kitchen despite of her modern } \\
\text { clothing } \\
\text { Salience given to men over the fem ale participant } \\
\text { Colours are emphasizing the brand identity, and creates } \\
\text { salience for the product, choice of font denotes modernity. } \\
\text { This advertisem ent will make the audience believe that } \\
\text { sim ilar m asculine and feminine appeals should be prom oted } \\
\text { in real life }\end{array}$ \\
\hline
\end{tabular}

1. Semiotic analysis of the first print advertisement - The print Ad of Maggie noodles published in December 2019. 


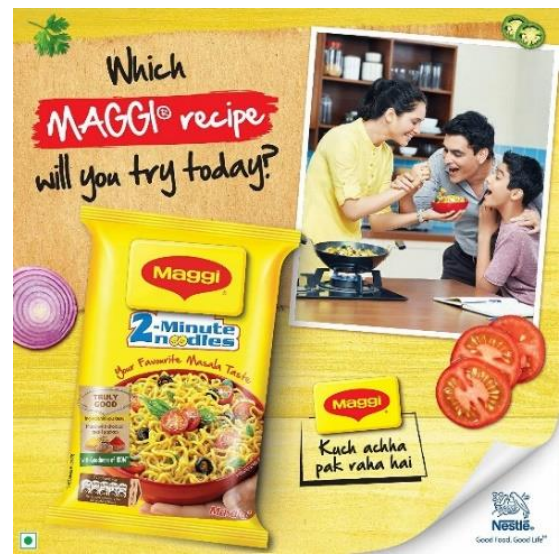

(Figure 1) Maggie Ad from Woman's Era - March 2020

The advertisement in figure 1 has three represented participants. One female participant and two male participants. All the participants represented in the advertisement are given importance through their positioning in the ad. The advertiser has used a specific social setting in the visual composition. The advertisement depicts a family having home-cooked Maggie in their kitchen. The setting and the choice of having a family for the advertisement of Maggie is consciously made to reach maximum audiences. Vectors are used to connect the participants and food. Vectors are used to connect the female participant to the males. The two male participants are savouring the cooked Maggie, which the female participant is feeding them. This reflects the ideologies of a patriarchal society where cooking and feeding is considered the responsibility of a woman.

The image demonstrates how it may lose credibility by obvious doctoring. To show that a contemporary family setting eats home-cooked food, they have carefully shown the participants in modern clothing. However, the female participant is portrayed in an ideal feminine domestic role confined to the kitchen, despite her modern outfit. This shows the conservative mentality of contemporary society, which is wrapped in western clothes. She is portrayed in such a way to be more acceptable to the Indian audience. The man in figure 1 is shown in workwear, which depicts that he is a working man. This advertisement will make the audience believe that similar masculine and feminine appeals should be promoted in real life. The image invites viewers to embrace the traditional system of family, the domestic role of a woman, and the salience given to the men supporting the views that men dominate society. The advertisement has used colours, fonts and foregrounding for creating salience. The advertisement has used foregrounding in promoting the product. The foreground is salient with the choice of yellow and red colours as attention-grabbing colours. Also, it is chosen carefully since it reinforces the brand identity through the colours. The image of the product in the foreground is to emphasise the importance of the product. Notably, the name and tagline are written in black, and white colour with thin font shows modernity. The advertiser cautiously chooses regional language for a tagline to target the native Hindi speaking audiences.

2. Semiotic analysis of the second print advertisement - The print Ad of Streax hair colour published in June 2020. 


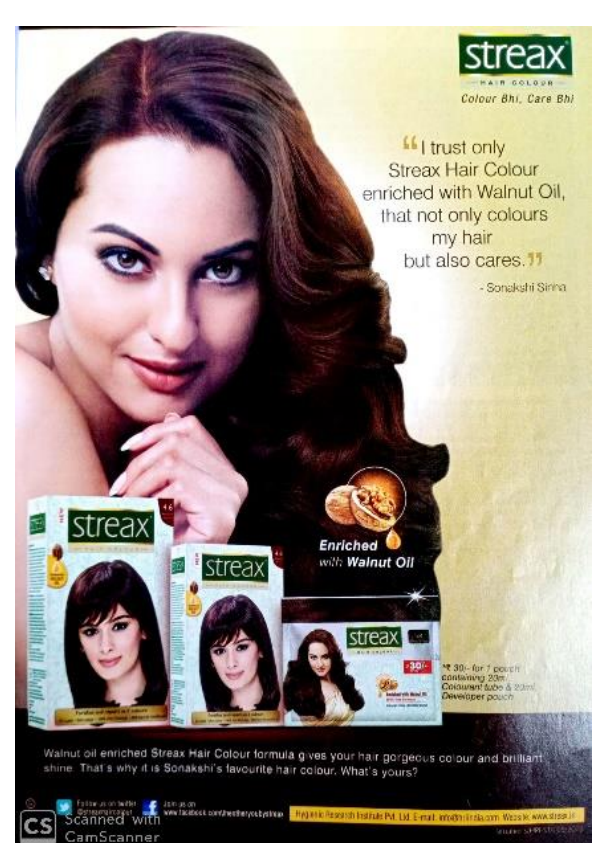

(Figure 2) Streax hair colour Ad from Femina - December 2019

\begin{tabular}{|c|c|c|}
\hline $\begin{array}{l}\text { Genders } \\
\text { represented in } \\
\text { the } \\
\text { advertisements }\end{array}$ & $\begin{array}{l}\text { Main vicual semiotic reso urces } \\
\text { used in the selected text }\end{array}$ & Meanings derived/messages being emitted in the text \\
\hline $\begin{array}{l}\text { Fem ale } \\
\text { participant } \\
\text { one } \\
\text { Male } \\
\text { participant- } \\
\text { zero }\end{array}$ & $\begin{array}{l}\text { 1. Eye gaze - vectors are used } \\
\text { to connect the ferm ale } \\
\text { participant the viewers } \\
\text { 2. Details of hair and tex ture, } \\
\text { bare hands and shoulders } \\
\text { 3. Face is represented aslarge- } \\
\text { round shaped } \\
\text { 4. Extrem ely fair-skin } \\
\text { 5. captured in horiz ontal frontal } \\
\text { ang ge } \\
\text { 6. close-up shot of the } \\
\text { participant } \\
\text { 7. placem ent of the product in } \\
\text { the foreground } \\
\text { 8. The tagine } \\
\text { 9. pale background colours } \\
\text { \&black and white thin font }\end{array}$ & $\begin{array}{l}\text { Aspirational- viewer is invited to purchase the product being } \\
\text { advertised } \\
\text { Sexual-viewer is invited to desire the modelemulate her } \\
\text { beauty } \\
\text { Objectification of wom an } \\
\text { Larger size im age-creating salience } \\
\text { Radiant face -is to represent the participant as a desirable idol } \\
\text { for youngsters } \\
\text { Fair skin is used to satiate the expectation of Indian audience- } \\
\text { reinforcing the colour discrimination in Indian society } \\
\text { soft bare skin-ideals of femininity } \\
\text { Horizontal ange allows the viewers to get involved with the } \\
\text { participant } \\
\text { Close-up shot- seduces the audience, forms a social } \\
\text { relationship b/w participant and viewers } \\
\text { Product placem ent emphasis the importance, tagine gives an } \\
\text { aspirational message } \\
\text { The thin font in black and white, signifies modernity and } \\
\text { classiness }\end{array}$ \\
\hline
\end{tabular}

The advertisement in figure 2 portrays a famous Indian actress. There is only a single participant in this ad. The participant is not doing anything and appears to be static. It appears to be an example of the conceptual process. The advertisement does not show any details of her outfit or any labels. The ad shows the bare skin of her hands and shoulders, and salience is created by keeping her image in a larger size, covering the majority of the ad. The fine details of her hair and its texture highlights 
the product quality. The bare shoulder and hands throw light at the mere objectification of the participant in a hair colour product advertisement. There is a symbolic attribution that she symbolises. Her face is shown as large round-shaped, and radiating like a full moon. The advertiser's intended message is to represent the participant as a desirable idol for youngsters. She is shown extremely fair skin to satiate the skin colour expectations of the Indian audience. It conveys a message to the young audience that fair skin is the only skin colour acceptable in society. The soft skin and fair complexion are reinforcing the ideals of femininity prevalent in the patriarchal society. The image tends to have a greater youth appeal. The image is captured in horizontal frontal angle and this allows the viewers to get involved with the participant in the image, rather than detached from them. The participant is forming a vector and connecting with the viewers through her gaze. The close-up shot of the participant and her seducing gaze at the viewers demands attention, and an imaginary social relationship is formed between the viewer and participant. An invitation to 'desire her' is reinforced by the vector that unfetters from the eye-line, connecting the participant directly with the viewer. She is establishing dominance over the viewer. The placement of the product in the foreground is to emphasise its importance. The tagline is 'aspirational' since she is a celebrity, marking her own experience in the tagline. The pale background colours highlight the participant's image, and the usage of black and white colours and thin line font signifying modernity and classiness.

3. Semiotic analysis of the third print advertisement - The print Ad of Exo bacto scrub published in January 2020.

The advertisement in figure 3 portrays a famous Indian celebrity. There is only one participant in this advertisement and it is female. The participant appears to be 'doing something' since she is in a standing position raising her hands and showing the viewers the product. She beckons to the viewers with the scrub she is holding. The participant fixes her gaze directly at the viewers, demanding their attention and asking them to enter an imaginary relationship with her.

\begin{tabular}{|c|c|c|}
\hline $\begin{array}{l}\text { Genders represented } \\
\text { in the advertisements }\end{array}$ & $\begin{array}{l}\text { Main visual semiotic } \\
\text { resources used in the } \\
\text { selected text }\end{array}$ & $\begin{array}{l}\text { Meanings derived/messages being emitted in the } \\
\text { text }\end{array}$ \\
\hline $\begin{array}{l}\text { Female participant - } \\
\text { one } \\
\text { Male participant-Zero }\end{array}$ & $\begin{array}{l}\text { 1. Eye gaze - } \\
\text { connecting the participant } \\
\text { with the viewers } \\
2 . \quad \text { Smiling and } \\
\text { welcoming face of the } \\
\text { female participant } \\
3 . \quad \text { Outfit of the } \\
\text { female participant } \\
4 . \quad \text { mid-close up shot } \\
5 \text { The red and green } \\
\text { colours The white colour } \\
6 . \quad \text { The red colour } \\
\text { thick line font } \\
7 . \quad \text { Foreground } \\
\text { font used for the tagline } \\
8 . \quad \text { placement of the product }\end{array}$ & $\begin{array}{l}\text { Social; exudes warmth, social affinity } \\
\text { Reflecting Indian family values } \\
\text { Outfit is carefully chosen for acceptance among } \\
\text { audience } \\
\text { Reflecting the ideologies of a patriarchal society } \\
\text { were woman is confined to kitchen } \\
\text { Stereotyped gender role and concept of femininity } \\
\text { prevalent in the ad } \\
\text { Target young and old Indian women } \\
\text { Mid-close up shot, establishes the feeling of } \\
\text { warmth and closeness } \\
\text { Choices of colours have given salience to the } \\
\text { product over the participant } \\
\text { The red and green colours signify brand identity, } \\
\text { energy, passion, action, determination and growth } \\
\text { The white colour thick line font represents purity } \\
\text { and modesty. The red colour font used for the } \\
\text { tagline denotes power and passion. }\end{array}$ \\
\hline
\end{tabular}




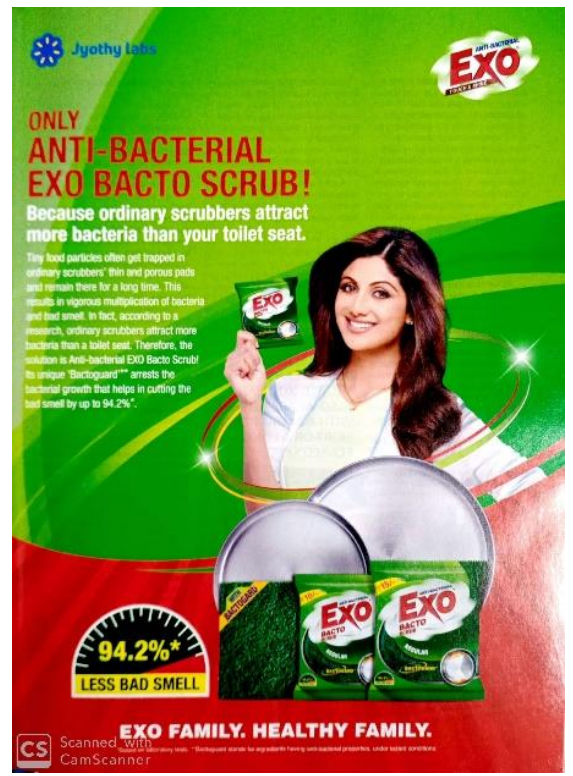

(Figure 3) Exo dishwash scrub Ad from Woman's Era - January 2020

She has a smiling and welcoming face, which are the expected attributes of an ideal Indian homemaker. She demands love and respect from ordinary viewers and supports her identity shown in the advertisement. The advertisement has consciously used a female participant for publicising the product since it is a dishwashing scrub. The viewers will be able to relate to it and will believe that washing dishes at home is a woman's responsibility. The stereotyped gender roles and the concept of femininity prevalent in the patriarchal society are reinforced by this image. The image invites the audience to purchase the product to achieve involvement and approval in the family setup. Her outfit is carefully chosen to be covering her skin and body to present her acceptable among the viewers. The product is using a female celebrity model to target young and old Indian women. She is wearing a white colour outfit which signifies love and peace. The mid-close upshot of the participant is used to maintain the social distance between the viewers and the participant. It is a relatively closer distance between the participant and the viewer, which establishes warmth and closeness. The choices of colours have given salience to the product over the participant. The red and green colours signify energy, passion, action, determination and growth respectively. It can also symbolise self-reliance with the use of a particular product. The white colour thick line font represents purity and modesty. The red colour font used for the tagline denotes power and passion.

\section{Conclusion}

The semiotic resources used for this study are gaze, angles, shots, colours, body postures, vectors and facial expressions. Based on the analysis, the study has found that the gender roles prevalent in the FMCG products print ads are majorly showing domestic and decorative/objectifying roles for women, out of three advertisements, two of them represented women in domestic roles with personality traits to be polite, accommodating and emotional. The advertisement of Streax hair colour product showed women as an ornamental object seducing the viewers. The Maggie ad portrayed the men as confident and aggressive.

Recurring themes found in representation are the portrayal of women in submissive roles, showing women in decorative roles and men in dominant roles. Also, having a family setting is another recurring theme derived from the analysis. This is because India is still a traditional society, and the viewers will accept the advertisement and product if they can relate to the themes.

Gender representation and product category - using women in the majority of FMCG products advertising. Out of the three advertisements selected for the study, all three used women participants for advertising the product. While men are not commonly shown in all FMCG product 
ads as frequently as women. This shows that FMCG products are more associated with women since they care for and nurture the family.

The relationship established between the represented participant in the advertisement and the viewer - The FMCG product advertisements tries to create a warm and close relationship between the product and the viewers through the participants. This is consciously done to bring the viewers closer to the product and make them want to buy it to fulfil their aspirations. The participants in the advertisements make the viewers believe that the "pseudo-reality" on the images are the actual reality in the world. It reinforces many conservative ideologies and values followed by society.

This study also demonstrates that FMCG products' advertisements reinforce specific values, such as a male-dominated family setting and the females being confined to servile roles compared to the men. As we know, media is the mirror of society, proving that these advertisements portray the rigid, conservative mentality entrenched within the Indian society even in the millennium. It seems that Indian women are yet to assume and experience more gender-challenged roles that break the stereotypes both on screen and in a real-life context.

\section{References}

1. Adham, S. A. (2012, March). A semiotic analysis of iconic representation of women in the middle eastern media (No. 1057810). Department of English, University of Birmingham. https://www.birmingham.ac.uk/Documents/college-

artslaw/cels/essays/matefltesldissertations/TFLASemioticAnalysisofthelconicRepresentationofWo menintheMiddleEasternMedia.pdf

2. Bovée, C. L., \& Arens, W. F. (1986). Contemporary Advertising. Irwin.

3. Dr. Alex, K., \& Mary Suthanthira Malar, M. (2017). A Study on Advertising Strategy of Fast Moving Consumer Goods (FMCG) Sector in India - With Special Reference to Trichy District. International Journal of Research - Granthaalayah, 1-8. https://doi.org/10.5281/zenodo.844786

4. Gilbert, P., \& Taylor, S. (1991). Fashioning the Feminine: Girls, Popular Culture, and Schooling (Australian Cultural Studies). Allen \& Unwin

5. Goffman, E. (1978). Gender Advertisements. Cambridge, MA: Harvard University Press. https://link.springer.com/book/10.1007/978-1-349-16079-2

6. Herman, E. S., \& Noam Chomsky. (1988). Manufacturing Consent: The Political Economy of the Mass Media. Vintage Books USA.

7. Indian Ad Spends Estimated to Grow at $10.7 \%$ in 2020: 's TYNY Report. (2020, May 8). GroupM. https://www.groupm.com/newsroom/indian-ad-spends-estimated-to-grow-at-10-7-in-2020groupms-tyny-report/

8. Kilbourne, W. E. (1990). Female Stereotyping in Advertising: An Experiment on Male-Female Perceptions of Leadership. Journalism Quarterly, 67(1), 25-31. https://doi.org/10.1177/107769909006700105

9. Kilbourne, J. (1999). Beauty and Beast of Advertising. Journal of Homosexuality, Vol.31(12).

10. Kilbourne, J. (2000). Can't buy my love: How advertising changes the way we think and feel. New York: Touchstone.

11.Ly, T. H., \& Jung, C. K. (2015). Multimodal Discourse: A Visual Design Analysis of Two Advertising Images. International Journal of Contents, 11(2), 50-56.

https://doi.org/10.5392/ijoc.2015.11.2.050

12.Pieters, R., Wedel, M., \& Batra, R. (2010). The Stopping Power of Advertising: Measures and Effects of Visual Complexity. Journal of Marketing, 74(5), 48-60. https://doi.org/10.1509/jmkg.74.5.48

13.Schudson, M. (1984). Advertising: The Uneasy Persuasion. Basic Boks, Inc.

14.Tavin, K. (2005). Opening Re-Marks: Critical Antecedents of Visual Culture in Art Education. Studies in Art Education, 47(1), 5-22. doi:10.2307/25475769

15.Topic: Advertising industry in India. (2020, September 17). Statista. https://www.statista.com/topics/2116/advertising-industry-in-india/\#dossierSummary_chapter2 
Study on Representation of Gender in Indian Print Media: A Semiotic Analysis of Fast Moving Consumer Goods (FMCG) Advertisements

16.Williamson, J. (1978). Decoding Advertisements: Ideology and Meaning in Advertising. Marion Boyars Publishers Ltd. https://research.uca.ac.uk/id/eprint/1493. 